\title{
JURISDICTION AND FREEZING INJUNCTIONS: A REASSESSMENT
}

The existing international scope of English freezing injunctions in support of foreign proceedings is excessively claimant-friendly and inconsistent with the need for a level playing field in litigation. The English courts must reconsider the current boundaries of relief by taking into account the international systemic perspective on the purpose of private international law rules. This theoretical perspective requires a multilateral and horizontal approach to the existence of jurisdiction rather than the unilateral and vertical approach that exists under the rules of jurisdiction of English national law. The traditional justifications for the availability of collateral freezing injunctions with respect to assets located abroad rest on a series of fundamental theoretical flaws. This paper proposes a range of reforms with the aim of strengthening the equality of the parties and eliminating encroachment on the sovereignty of foreign states.

\section{Introduction}

The availability of freezing injunctions is one of the key factors attracting international commercial litigation to the English courts. ${ }^{1}$ Although litigants can obtain some sort of asset preservation relief in other legal systems, a unique feature of English freezing injunctions is their extensive international scope and flexibility to address the most creative attempts to dissipate assets. ${ }^{2}$ Not only is it possible to obtain a freezing injunction over a defendant's assets located abroad, but such an order may be collateral to foreign substantive proceedings. ${ }^{3}$ One of the justifications for such a wide international scope of freezing injunctions is said to be the need to prevent unscrupulous defendants from exploiting territorial boundaries for the purposes of making themselves judgment-proof.

A related policy underpinning worldwide freezing injunctions collateral to foreign proceedings is the apparent need for English courts to provide assistance to foreign courts, especially in the context of tackling international fraud. ${ }^{4}$ To give effect to these policy goals, courts have relied on the equitable characteristics of freezing injunctions. In particular, the courts have artificially stretched the principle that injunctions operate in personam by interpreting this as a licence to extend freezing injunctions to assets located outside their territorial jurisdiction. In doing so the courts may have lost sight of relevant principles of

\footnotetext{
${ }^{1}$ See Fentiman R., 'Theory and Practice in International Commercial Litigation' (2012) 2 IJPL 235; McLachlan C., 'International Litigation and the Reworking of the Conflict of Laws' (2004) LQR 580.

2 The term 'scope' can be used to refer to two aspects of freezing injunctions. The first aspect involves the substantive circumstances in which a freezing injunction is available, such as its availability in support of both proprietary and non-proprietary claims (the author refers to this as the 'substantive scope' of freezing injunctions). The second aspect is the availability of a freezing injunction in cases involving one or more foreign elements such as the use of freezing injunctions to restrain a foreign defendant from dissipating any assets located abroad (hereinafter, the 'international scope').

${ }^{3}$ See, inter alia, Republic of Haiti v Duvalier [1990] 1 Q.B. 202 ('Duvalier').

${ }^{4}$ Credit Suisse v Cuoghi [1998] Q.B. 818 ('Credit Suisse'). For critique of this reasoning, see Briggs A., Private International Law in English Courts (OUP: Oxford, 2014).
} 
public and private international law. It will be argued that the manner in which the English courts address the issue of international jurisdiction in the context of freezing injunctions is incompatible with the functions of jurisdictional rules in private international law. The root of this problem is that the application of English common-law rules of jurisdiction in freezing injunction cases is based on an overly narrow view that principles of public international law do not have any impact on the limits of jurisdiction in civil litigation.

The first objective of this article is to examine the international scope of freezing injunctions and determine whether the current practice is satisfactory. The second related objective is to examine whether there is illegitimate interference with the sovereignty of other states in the context of freezing injunctions. The article focuses on freezing injunctions in support of foreign substantive proceedings ('collateral freezing injunctions'), as this is the most controversial and problematic category of freezing injunctions. It will be argued that the current balance of rights between the parties fails to achieve a level playing field. This is because the courts take a claimant-friendly and theoretically flawed approach to the application of private international law rules in freezing injunction cases. Such an approach creates the potential for unjustifiable encroachment on the sovereignty of foreign courts.

It is submitted that the courts should reconsider the international scope of freezing injunctions by taking into account the international systemic perspective on the purpose of private international law rules. ${ }^{5}$ This theoretical perspective requires a multilateral and horizontal approach to the existence of jurisdiction as opposed to the unilateral and vertical approach under the current regime. ${ }^{6}$

Restrictions on the international scope of freezing injunctions are urgently required to ensure a level playing field in international litigation. Under the current approach financially strong claimants are able to make multiple applications for asset preservation relief with respect to the same assets. A further aspect of potential unfairness to defendants is that the current stance on jurisdiction creates an increased risk of wrongfully granted freezing injunctions.

\section{An overview of the current scope of relief}

The approach under section 25 Civil Jurisdiction and Judgments Act 1982

The current approach to applications under section 25 of the Civil Jurisdiction and Judgments Act 1982 has been described as a two-step analysis. ${ }^{7}$ The first question for the court is whether a freezing injunction would be granted if the substantive proceedings were in England. If the answer is in the affirmative, then the second step for the court is to decide whether it would be "inexpedient" to grant the freezing order.

\footnotetext{
${ }^{5}$ On the international systemic perspective, see Mills A., The Confluence of Public and Private International Law (Cambridge: Cambridge University Press, 2009).

${ }^{6}$ This article does not analyse the consistency of jurisdictional theories with the current framework for freezing injunctions in support of foreign proceedings in another European Union Member State. This is primarily because, in the author's view, the rules of jurisdiction in Regulation (EU) 1215/2012 of the European Parliament and of the Council of 12 December 2012 on jurisdiction and the recognition and enforcement of judgments in civil and commercial matters ('Brussels I Recast Regulation') are not unilateral and vertical, in contrast to the common law rules of jurisdiction. Here, the focus is on the residual common law rules of jurisdiction.

${ }^{7}$ Refco Inc v Eastern Trading Co. [1999] Lloyd's Rep 159 ('Refco'), 170-171.
} 
Personal jurisdiction over the defendant

As freezing injunctions are regarded as operating in personam, it is necessary to establish personal jurisdiction over the defendant. If the defendant is present in England, the application notice for the injunction may be served on the defendant without the court's permission. In cases involving service on the defendant outside the jurisdiction, CPR PD6B 3.1(5) provides a straightforward ground of jurisdiction.

\section{Orders which cover assets abroad}

What about jurisdiction over assets? Section 25 of the 1982 Act is silent about the territorial scope of a freezing injunction in support of foreign proceedings. However, the Court of Appeal has made it clear that it is possible for a claimant to obtain a worldwide freezing injunction from an English court in support of foreign substantive proceedings. ${ }^{8}$

In applying section 25(2) of the 1982 Act, the court must be satisfied that it is not "inexpedient" to grant the injunction. There are several important decisions of the Court of Appeal on the application of the test of expediency. ${ }^{9}$ Whether the presence of assets in England (without any additional connection to England) is sufficient to justify a worldwide freezing injunction is not entirely clear due to the existence of conflicting decisions on this point. ${ }^{10}$

Significantly, it appears that an English court may exercise its discretion to grant a collateral freezing injunction even where there is minimal or no connection to the forum. ${ }^{11}$ In cases such as these, the claimant must show some "exceptional circumstances", largescale international fraud probably being the best example. ${ }^{12}$

\footnotetext{
${ }^{8}$ See, for example, Motorola v Uzan (No 2) [2003] EWCA Civ 752. Prior to the decision in Babanaft v Bassatne [1990] Ch 13, it was not possible to obtain any freezing injunction regarding assets located abroad: Ashtiani $v$ Kashi [1987] Q.B. 888 and Intraco Ltd v. Notis Shipping Corporation (The Bhoja Trader) [1981] A.C. 557.

${ }^{9}$ See especially Credit Suisse v Cuoghi [1998] Q.B. 818, Refco v Eastern Trading [1999] Lloyd's Rep 159, and Motorola v Uzan (No 2) [2003] EWCA Civ 752.

${ }^{10}$ Motorola v Uzan (No 2) [2003] EWCA Civ 752 (worldwide freezing injunction granted to restrain one of the defendants whose only connection to England was the existence of English assets); Banco Nacional de Comercio Exterior SNC v Empresa de Telecommunicaciones de Cuba SA [2007] EWCA Civ 662 (the existence of English assets was not sufficient to justify a worldwide freezing injunction). For criticism of the court's reasoning in Motorola v Uzan (No 2), see Fentiman R., 'The Scope of Transnational Injunctions' (2013) 11 NZJPIL 323.

${ }^{11}$ See, inter alia, Royal Bank of Scotland PIC v FAL Oil Company Ltd [2012] EWHC 3628 (Comm); ICICI Bank UK v Diminco NV [2014] EWHC 3124 (Comm) ('Diminco'); Eastern European Engineering Ltd v Vijay Construction (Proprietary) Ltd [2018] EWHC 1539 (Comm).

${ }^{12}$ See, inter alia, Mobil Cerro Negro Ltd v Petroleos de Venezuela SA [2008] EWHC 532 (Comm); Belletti v Morici [2009] EWHC 2316 (Comm); ICICI Bank UK v Diminco NV [2014] EWHC 3124 (Comm). For criticisms relating to the requirement for exceptional circumstances, see the section of this article entitled "Cases involving no connection with England".
} 
In addition to the test of expediency, a further requirement at the discretionary stage is compliance with the principle of comity. ${ }^{13}$ The problem is that there is no clear guidance on the circumstances in which the principle of comity would justify a refusal to grant a collateral freezing injunction.

\section{Does England have to be the most appropriate forum?}

With the exception of some obiter statements in only one case, ${ }^{14}$ the courts have not directly considered the question of whether England is a clearly more appropriate forum to determine the availability of asset preservation relief. In other words, in cases on freezing orders where the claimant has relied on paragraph 3.1(5) of Practice Direction 6B to serve the defendant out of the jurisdiction, the courts have accepted the existence of jurisdiction and avoided the application of the principle of forum conveniens. On the other hand, it could be argued that the courts have perhaps indirectly addressed the question of whether England is a clearly more appropriate forum through their application of the test of expediency. From this perspective, any factors that would be relevant for the purposes of a forum conveniens enquiry are subsumed into the list of five factors identified by the Court of Appeal in Motorola v Uzan (No 2) ${ }^{15}$ as being relevant for the purposes of the criterion of expediency:

"First, whether the making of the order will interfere with the management of the case in the primary court, e.g., where the order is inconsistent with an order in the primary court or overlaps with it...Second, whether it is the policy in the primary jurisdiction not itself to make worldwide freezing/disclosure orders. Third, whether there is a danger that the orders made will give rise to disharmony or confusion and/or risk of conflicting inconsistent or overlapping orders in other jurisdictions, in particular the courts of the state where the person enjoined resides or where the assets affected are located....Fourth, whether at the time the order is sought there is likely to be a potential conflict as to jurisdiction rendering it inappropriate and inexpedient to make a worldwide order. Fifth, whether, in a case where jurisdiction is resisted and disobedience to be expected, the court will be making an order which it cannot enforce" ${ }^{16}$

\section{Concerns about the current scope of relief}

Let us begin with a hypothetical case. The context is an international sale of goods on CIF terms. A dispute has arisen between a Japanese seller and a Russian buyer. The buyer refuses to pay for the goods on the basis that the bill of lading is allegedly inconsistent with

\footnotetext{
${ }^{13}$ Refco Inc v Eastern Trading Co. [1999] Lloyd's Rep 159; Masri v Consolidated Contractors International (UK) Ltd [2009] Q.B. 450 ('Masri (No 2)').

${ }^{14}$ See Cruz City 1 Mauritius Holdings v Unitech Limited [2014] EWHC 3704 (Comm), [85]-[90] (although this was in the context of an application for a freezing injunction in aid of enforcement of a London arbitration award).

${ }^{15}$ Apart from the Court of Appeal's guidance in Motorola v Uzan (No 2) [2003] EWCA Civ 752, the Commercial Court has also provided a list of relevant considerations in ICICI Bank UK v Diminco NV [2014] EWHC 3124 (Comm). As this is a relatively recent and important 'update' on the relevant considerations, it is discussed in detail in the section of this article entitled "Cases involving no connection with England".

${ }^{16}$ Motorola (No 2) [2003] EWCA Civ 752, [115].
} 
the requirements stipulated in the sale contract. The buyer's main asset is a bank account at the New York branch of an English bank. The bank account is governed by New York law, whereas both the sale contract and the bill of lading are governed by English law. The seller contemplates launching substantive proceedings in New York. In the New York District Court, the seller's application for pre-judgment attachment is unsuccessful because of the failure to demonstrate intention to defraud. Nevertheless, the seller subsequently obtains an ex parte, pre-judgment worldwide freezing injunction from the English court.

\section{Potential unfairness to the defendant}

The claimant's ability to obtain the ex parte order from the English court is a powerful tactical device that may force the defendant to give security or settle on an unfavourable basis. As Lord Bingham explained, freezing injunctions "are not granted to give a claimant advance security for his claim, although they may have that effect". ${ }^{17}$ Even the publicity generated by the granting of a freezing order can have an important impact. In Mobil Cerro Negro Ltd. $v$ Petroleos de Venezuela $S A,{ }^{18}$ the claimant obtained an ex parte worldwide freezing order. While the order was later discharged, an article from Reuters about the freezing order, ${ }^{19}$ published before the inter parte hearing, could have caused damage to the reputation of the defendant. ${ }^{20}$

Another issue arising from the hypothetical example is whether the application of the English rules of jurisdiction in the context of injunctive relief is unfair to defendants in that there is no mechanism to stop the claimant at the outset from relitigating an issue that had already been considered by a foreign court. Such relitigation could be regarded as abusive forum shopping. ${ }^{21}$ If there are different requirements for obtaining interim relief in England and New York, should claimants be free to pick and choose whichever procedural rules offer them the most favourable substantive preconditions for obtaining a freezing injunction or equivalent form of protection ${ }^{22}$

Potential infringement of the interests of a foreign state

Apart from unfairness to the defendant, there is a concern in the hypothetical example about the interests of foreign states. Is the English court illegitimately interfering with New York's sovereignty? The question for the court in our hypothetical case is whether a Russian defendant should be restrained from exercising his contractual rights under a

\footnotetext{
${ }^{17}$ Fourie v Le Roux [2007] 1 WLR 320.

18 [2008] EWHC 532 (Comm).

19 'Courts freeze $\$ 12$ billion Venezuela assets in Exxon row', $7^{\text {th }}$ February 2008, Reuters:

http://www.reuters.com/article/us-exxon-venezula-idUSN0741426720080207

${ }^{20}$ Gloster LJ observed that freezing injunctions "carry a reputational stigma" in her judgment in Candy $v$ Holyoake [2017] EWCA Civ 92, [36].

${ }^{21}$ Some instances of forum shopping could be regarded as legitimate rather than abusive, see Bell A., Forum Shopping and Venue in Transnational Litigation (Oxford: Oxford University Press, 2003). See also Merrett L., 'Abuse of Rights and Forum Shopping' (Cambridge Private Law Centre Seminar Paper, 7th March 2013), who points out, at fn.5, that "[a]ttempting to relitigate an issue that has already been decided has also been described as forum shopping" and the examples provided therein.

${ }^{22}$ The term 'substantive preconditions' is used in this article to denote all preconditions other than those arising from the rules of private international law. The main substantive preconditions include a good arguable case on the merits and a real risk of dissipation of the assets.
} 
bank account governed by New York law. Is this a question which the English court should be adjudicating upon simply because the substantive dispute over the sale contract is governed by English law? If so, the consequence is concurrent jurisdiction and a possible conflict of procedural laws: ${ }^{23}$ under New York law, the defendant is lawfully and freely allowed to deal with his assets, whereas under English law, any such dealing would amount to contempt of court, as it would constitute a breach of the freezing injunction. Thus, by granting a worldwide freezing injunction, the English court could be seen as encroaching upon the regulation of the defendant's rights acquired under New York law.

As Rogerson explained, "[i]t is only where the case is going ahead in a forum... which is not anticipated by the parties and to the substantial benefit of one of them that the choice of forum could be said to be unjust...a party seeking out an unconnected forum merely to gain an advantage can be considered an abusive forum shopper" ${ }^{24}$ There is no doubt that the ability to obtain an ex parte worldwide freezing injunction from the English court is a substantial benefit to the claimant. Furthermore, the Russian buyer in this example would not have been able to anticipate that an application before the English court could have serious implications for its dealings with assets located abroad.

\section{Evidence of a more cautious approach}

In light of the concerns outlined above, it is not surprising that more recent decisions illustrate a more cautious approach.

A controversial issue which had to be addressed was whether the court's ability to enforce the injunction in England should be a sufficient justification for establishing jurisdiction to grant a worldwide freezing order. The enforceability of the injunction is a relevant consideration in that it would be futile for the courts to grant unenforceable orders. However, to use the injunction's enforceability as a justification for jurisdiction creates a risk of regulating a foreign defendant's conduct in relation to assets located abroad whenever it is possible for the court to seize some assets in England. An 'early' example of a cautious approach and a judgment recognising the need to separate the question of the existence of jurisdiction from the question of the enforceability of the injunction is that of Walker J in Mobil Cerro Negro. ${ }^{25}$ As Walker J explained,

"I do not accept that the true nature of the focus on a need for some connection with England and Wales, in cases under s. 25, is merely the desirability that the court should have some means of enforcing its order, especially in circumstances where the court knew that those subject to that order would disobey it. That desirability may well be highly relevant or even determinative. It is not, however, the same thing as consideration of the extent to which it is appropriate for this court to make an order affecting assets not located here."26

\footnotetext{
${ }^{23}$ See Lord Donaldson MR's warning about "criss-crossing long arm jurisdictional orders" in Rosseel NV $v$ Oriental Commercial Shipping (UK) Ltd [1990] 1 WLR 1387, 1388 G/H - 1389 D. For the application of Lord Donaldson MR's reasoning, see S \& T Bautrading v Nordling [1997] 3 All ER 718.

${ }^{24}$ Rogerson P., Collier's Conflict of Laws (Cambridge: Cambridge University Press, 2013), pp. 140-141.

${ }^{25}$ Mobil Cerro Negro Ltd v Petroleos de Venezuela SA [2008] EWHC 532 (Comm). For comments on this case, see Johnson A., 'Interim Injunctions and International Jurisdiction' (2008) 27 CJQ 433.

${ }^{26}$ [2008] EWHC 532 (Comm).
} 
While Walker J made several references to "considerations of comity", it appears that he did not provide a clear explanation of their content or of how such considerations have an effect on the court's exercise of discretion. The explanation could lie in his emphasis on the requirement of a "sufficiently strong link" with England in the absence of exceptional circumstances such as fraud. Thus, a possible interpretation is that he equated comity with the requirement of a sufficiently strong link. ${ }^{27}$ Walker J expressly noted that the court cannot proceed on the assumption that "presence of the respondent here will necessarily be sufficient to warrant the exercise of discretion in favour of an applicant - although...it may weigh in favour of granting relief". ${ }^{28}$

The cautious approach of Walker J should be applauded, particularly his careful separation of jurisdictional and enforcement issues. The outcome in Mobil is undoubtedly correct. Nevertheless, the reasoning is still inconsistent with a multilateral approach to the existence of jurisdiction.

The most significant question-whether the English rules on freezing injunctions were applicable at all-should not be left to the discretionary stage. If the English court had first addressed the question of its regulatory authority in relation to assets located abroad, it would not have been necessary to spend any time addressing the arguments about the test of expediency. Given the complete absence of any connection between the defendant and England, there should have been no jurisdiction to grant the injunction at all.

Importantly, a more cautious approach has been adopted by the Court of Appeal, as evident from the reasoning in Masri (No 2). Lawrence Collins $\amalg$ (as he then was) expressly stated that

"the mere fact that an order is in personam and is directed towards someone who is subject to the personal jurisdiction of the English court does not exclude the possibility that the making of the order would be contrary to international law or comity, and outside the subject-matter jurisdiction of the English court." 29

Furthermore, Lawrence Collins LJ observed that

"the extension of the Mareva jurisdiction to assets abroad was justifiable in terms of international law and comity provided that the case had some appropriate connection with England, that the court did not purport to affect title to property abroad, and that the court did not seek to control the activities abroad of foreigners who were not subject to the personal jurisdiction of the English court" ${ }^{30}$

\footnotetext{
27 The language of "sufficient interest" or "connection" and its link to the principle of comity was initially developed by Lord Goff in the context of anti-suit injunctions in Airbus v Patel [1999] 1 A.C. 119. For an argument that a sufficient interest in, or connection with, the matter in question is a necessary (but not a sufficient) condition for compliance with comity; see Fentiman R., 'The Scope of Transnational Injunctions' (2013) 11 NZJPIL 323.

28 Ibid.

${ }^{29}$ Masri v Consolidated Contractors International (UK) Ltd (No 2) [2009] Q.B. 450, 465.

30 Ibid, 465.
} 
, The problem with the requirement of "sufficient connection" is threefold. First, it is not possible to give clear legal advice on what the court will deem to be a sufficient connection. The concept of sufficient connection, as it currently stands, is open to creative extensions by counsel and the courts, and it is therefore unsuitable for the purposes of determining the scope of regulatory authority in the field of interim relief. Second, the requirement of sufficient connection cannot eliminate concurrent jurisdiction (in relation to the same assets) and the consequent unfairness to defendants. Third, the English courts' consideration of the issue of sufficient connection (just like the principle of comity) is currently treated as an element of whether the court should exercise its discretionary power to grant a freezing injunction. Under the current approach, sufficient connection is not treated as a matter relevant to the existence of jurisdiction.

The influence of the reasoning of Lawrence Collins $L J$ in Masri (No 2) was reflected in the Commercial Court's decision in The Mahakam. This decision could be regarded as further recognition that despite their in personam classification, freezing injunctions with respect to assets located abroad actually involve a subtle interference with the sovereignty of foreign courts. Although the Singaporean company in The Mahakam submitted to the jurisdiction of the English court through its failure to contest its jurisdiction, this was not sufficient for the court to regulate its conduct abroad. In response to Lawrence Collins LJ's warning about the limits of personal jurisdiction in Masri (No 2), the Commercial Court in The Mahakam was cautious about the territorial scope of injunctive relief: even though the court had personal jurisdiction over the Singaporean company (as a result of submission to the jurisdiction), worldwide relief was refused and the injunction was limited to the assets located in England. ${ }^{31}$

\section{The legal and policy arguments in favour of reform}

In the following setion it will be suggested that there are theoretical flaws in the current regime. In particular, a detailed assessment is required of the consistency of the current regime with the principles of private international law, public international law, and the theoretical foundations for the existence of freezing injunctions. Such an assessment will make it possible to provide suitable recommendations for reform.

\section{A. The purpose of private international law rules}

The traditional view, which reflects the approach of the 'national school', is that private international law is a set of rules that form part of national law and whose purpose is to avoid the injustice and inconvenience that would result from subjecting cases with a foreign element to the same treatment as purely domestic disputes. ${ }^{32}$ However, the 'internationalist school' argues that public international law provides an external foundation for private international law. Mann famously submitted that

\footnotetext{
${ }^{31}$ For a further explanation of the reasoning in The Mahakam, see section $\mathrm{V}(\mathrm{B})(2)$ below.

${ }^{32}$ See, for example, Collins L., The Conflict of Laws (Sweet \& Maxwell, $15^{\text {th }}$ edn, 2016), chapter 1; Bogdan M., Private International Law as Component of the Law of the Forum (Hague Academy of International Law, 2012), esp. p. 41.
} 
"All States have introduced rules of private international law and, indeed, a strong body of opinion asserts that every country is under a duty to have rules of private international law, that it would be a breach of an international duty if the lex fori applied in all circumstances." ${ }^{33}$

A contemporary version of this approach, which adopts an "international systemic perspective", is that private international law provides a framework for selecting the legal system applicable to an event or set of facts. ${ }^{34}$ In other words, it is seen as a system of international ordering administered by national courts. Private international law is not concerned only with ensuring outcomes in individual cases but with the justness of international legal ordering. It is not concerned with private rights but with public powers. It recognises that there is no hierarchy of national private laws and their respective standards of justice. Therefore, it seeks to preserve the diversity of national laws and promotes justice, pluralism and subsidiarity. ${ }^{35}$ International coordination of the national rules of private law is necessary to reduce the inconsistent legal treatment of an event or set of facts. ${ }^{36}$ The international systemic perspective involves a rejection of the sharp distinction between private and public international law.

\section{B. The confusion surrounding the concept of jurisdiction}

The importance of being clear about the meaning of the term jurisdiction cannot be overestimated. It is possible to categorise jurisdictional rules in several ways. The failure to distinguish between different types of jurisdiction and the tendency to use the terminology interchangeably is one of the main factors contributing to the theoretical flaws in the current application of private international law rules in the context of freezing injunctions. The first step is to explain the dual purpose of jurisdictional rules in private international law.

\section{The purpose of jurisdictional rules}

The rules of adjudicatory jurisdiction in private international law can be said to have tworoles, which serve international and private purposes. The international purpose of adjudicatory authority is essentially concerned with the horizontal relationship among the states, while the private purpose of adjudicatory authority materialises in a vertical dimension between the state and individuals. The dual role of jurisdiction rules recognises that private international law has moved beyond the national school of thought by

\footnotetext{
${ }^{33}$ Mann F.A., 'The Doctrine of Jurisdiction in International Law' (1964) 111 Recueil des Cours 1. Mann regarded territorial sovereignty as the root of private international law rules of jurisdiction.

${ }^{34}$ See Mills A. The Confluence of Public and Private International Law (Cambridge: Cambridge University Press, 2009). See also Singer J.W. 'Real Conflicts' (1989) 69 Boston U. L. Rev. 1. The latter criticises the view that the forum should simply adopt private international law rules that further the goals of its substantive laws. A forum must have a multistate concern about appropriate tolerance and respect for the choices of other normative and political communities.

35 Mills A., The Confluence of Public and Private International Law (Cambridge: Cambridge University Press, 2009), pp. 5-6.

36 Ibid, pp. 16-17.
} 
embracing the international systemic perspective. Regarding the international purpose of jurisdiction rules, the main objective is to protect sovereignty through demarcation:

"restrictions on choice of law protect a state seeking to regulate local activities only against application of the substantive law of the forum state. By contrast, restrictions on personal jurisdiction ensure that disputes will be resolved in accordance with the entire legal environment of the regulating state." ${ }^{37}$

Protection of sovereignty through jurisdiction rules is crucial because these rules have a direct impact on the extent to which the forum's procedural law (including any injunctive relief) regulates matters not exclusively of domestic concern. Mills observed that "without rules of jurisdiction...no dispute over whose regulatory authority should apply to a person or event would be capable of being resolved through law". ${ }^{38} \mathrm{~A}$ number of commentators have underscored the link between rules of jurisdiction and their impact on the outcome of the case. As Maier and McCoy argued, "[o]nce it is conceded that a forum has judicial jurisdiction, that forum unavoidably controls or determines the result in the case between the parties before it-even if the forum court decides to apply a foreign state's rule of law". ${ }^{39}$ Similarly, Brilmayer stated that "the exercise of adjudicatory authority is a form of regulation whether or not the forum applies its own law". ${ }^{40}$ This inextricable link between adjudicatory jurisdiction and regulatory authority (also known as legislative jurisdiction) is of particular importance in the context of adjudicatory jurisdiction over freezing injunctions because of their quasi-proprietary nature and the fact that there is no room for the application of foreign law on pre-judgment asset preservation relief. ${ }^{41}$

What about the private purpose of the rules of adjudicatory jurisdiction? There is a close link between the international purpose of the rules of adjudicatory jurisdiction and their private purpose because "[I]imits on the forum state's sovereign authority protect both the regulatory power of other states and a liberty interest of defendants who plan their behaviour to conform to the regulatory scheme of the jurisdiction in which they act." 42 Defendants cannot plan their behaviour without clear and predictable rules about the applicable regulatory scheme. If the defendants and their commercial dealings have connections with more than one jurisdiction, they must know the regulatory scheme with which they must comply to assess their risks. ${ }^{43}$ Defendants may have legitimate expectations about which regulatory scheme is applicable.

One of the significant theoretical flaws in the current international scope of freezing injunctions is that with some limited exceptions, the English courts have failed to take proper account of the international function of private international law's rules of jurisdiction. From a theoretical perspective, this reluctance to give weight to the interests of foreign states may be explained by the English common law's allegiance to the traditional

\footnotetext{
${ }^{37}$ Sterk S.E., 'Personal Jurisdiction and Choice of Law' (2012) 98 lowa L. Rev. 101, pp. 113-114.

${ }^{38}$ See Mills A., 'Rethinking Jurisdiction in International Law' (2014) 84(1) BYIL 187, 188.

${ }^{39}$ Maier H.G. and McCoy T.R., 'A Unifying Theory for Judicial Jurisdiction and Choice of Law' (1991) 39 Am. J. Comp. L. 249, 255.

${ }^{40}$ Brilmayer L., 'Related Contracts and Personal Jurisdiction' (1988) 101 Harv. L. Rev. 1444.

${ }^{41}$ For an explanation of the quasi-proprietary nature of freezing orders, see the section of this article entitled

"The quasi-proprietary nature of freezing injunctions".

${ }^{42}$ Sterk S.E., 'Personal Jurisdiction and Choice of Law' (2012) 98 lowa L. Rev. 101.

${ }^{43}$ See Fentiman R., International Commercial Litigation (Oxford: Oxford University Press, $2^{\text {nd }}$ edition, 2015).
} 
view (the national school) of the purpose of private international law. Under this traditional view, the existence of jurisdiction is a domestic matter ${ }^{44}$ regardless of whether the legal system adopts a power-, relational-, or fairness theory. The existence of jurisdiction depends entirely on whether the case falls within or outside the limits set by national law for its own courts. The traditional view underpins what Michaels describes as "the US paradigm of jurisdiction". ${ }^{45}$ This paradigm of jurisdiction is usually characterised by vertical, unilateral, domestic, and political approaches to jurisdiction.

If we take the international systemic perspective, the rules of adjudicatory jurisdiction function as one of the means for ensuring the appropriate coordination of different national laws. From this perspective, the existence of jurisdiction is an international question rather than a question of whether the parties are within or outside of the jurisdiction. The international systemic perspective could be regarded as underpinning what Michaels describes as "the European paradigm of jurisdiction". The characteristics of this paradigm are usually horizontal, multilateral, international, and apolitical rules on the existence of jurisdiction. ${ }^{46}$ Multilateral rules of jurisdiction are designed to avoid concurrent jurisdiction.

It is submitted that the multilateral approach to the existence of jurisdiction should be the preferred approach and is consistent with the theory that private international law rules are affected by public international law. This is because the rules on the existence of jurisdiction are an exception to the dualist conception of the relationship between domestic and international law:

"The sovereignty paradigm holds that states are the ultimate and supreme political entities within their jurisdictional realms. Dualism interprets this to mean that states are self-contained, autonomous political entities with the capacity to determine which laws their own courts and other administrative institutions will follow. While the sovereignty paradigm gives the state the ability to control its own internal organs of administration, this control cannot extend to directing these organs to define the state's jurisdictional power itself. The state cannot grant its courts powers that it itself does not already have. Because, under the sovereignty paradigm, the definition of the state and its corresponding powers to exercise jurisdiction come from international law, under this paradigm these jurisdictional powers cannot be interpreted to provide that the state itself has the power to define their scope." ${ }^{47}$

It follows that, as a matter of international obligation, states should not unilaterally prescribe their own rules on the existence of jurisdiction in cases with a foreign element. Such unilateral action would amount to an attempt to prescribe international law in the

\footnotetext{
${ }^{44}$ For the purposes of English common law rules of jurisdiction, a distinction must be made between the existence of jurisdiction and the exercise of jurisdiction. The rules regarding the former are concerned with the power of the national courts to adjudicate the case, whereas the latter rules determine whether the court will exercise its power to adjudicate the case.

${ }^{45}$ Michaels R., 'Two Paradigms of Jurisdiction' (2005-2006) 27 Mich. J Int'I L. 1003.

46 Ibid, p. 1045-1048.

47 Strauss A.L., 'Beyond National Law: The Neglected Role of International Law of Personal Jurisdiction in Domestic Courts' (1995) 36 Harv. Int'I. L.J. 373, 414-415.
} 
international realm. ${ }^{48}$ Consistent with the international systemic perspective, Mills has explained that

"rules concerned with the existence of jurisdictional authority cannot reflect national policies or values because this would beg the question as to whether there is power to apply those policies. This component of the determination of jurisdiction cannot be based on a national conception of private rights because no national system could provide authority for a decision that such rights exist; it must therefore be international in character." 49

Furthermore, convincing normative arguments have been advanced for applying the international law of jurisdiction rather than giving each state the freedom to draw its own jurisdictional boundaries. ${ }^{50}$ Only a coordinated, multilateral system of international jurisdictional rules would "promote an effective system of dispute resolution whereby opportunities for forum shopping will be minimised, foreign judgments will be satisfied, and jurisdictional conflicts will be avoided". ${ }^{51}$

\section{Categories of jurisdictional rules in freezing injunctions cases}

Personal jurisdiction over the defendant (jurisdiction in personam) is concerned with the legal power to summon the defendant before the court. ${ }^{52}$ Whereas personal jurisdiction is jurisdiction over the person, jurisdiction in rem is jurisdiction over property. The latter is generally based on the presence of property (res) within the territorial jurisdiction of the forum. In freezing injunctions cases, personal jurisdiction over the defendant is currently regarded as a sufficient requirement to establish the existence of the English court's jurisdiction to grant a freezing injunction. The basic justification for this position is the widely held view that freezing injunctions operate in personam. ${ }^{53}$ However, personal jurisdiction over the defendant should not be regarded as the only requirement imposed by

\footnotetext{
${ }^{48}$ Ibid, p. 415.

${ }^{49}$ Mills A., The Confluence of Public and Private International Law (Cambridge University Press, 2009), p. 7. See also Beale J., 'Jurisdiction of a Sovereign State' (1923) 36 Harv. L. Rev. 241, 241 who states that "the sovereign cannot confer jurisdiction on his courts or his legislature when he has no such jurisdiction according to the principles of international law".

${ }^{50}$ Strauss A.L. 'Beyond National Law: The Neglected Role of International Law of Personal Jurisdiction in Domestic Courts' (1995) 36 Harv. Int'I. L.J. 373, 416-423. For a contrary view, see Akehurst M., 'Jurisdiction in International Law' (1973) 46 British Yearbook of International Law 145, 176-177 who concludes that "[i]n practice the assumption of jurisdiction by a State does not seem to be subject to any requirement that the defendant or the facts of the case need have any connection with that State; and this practice seems to have met with acquiescence by other States...(apart from the well-known rules of immunity for foreign States, diplomats, international organizations, etc.) customary international law imposes no limits on the jurisdiction of municipal courts in civil trials".

51 Strauss A.L. 'Beyond National Law: The Neglected Role of International Law of Personal Jurisdiction in Domestic Courts' (1995) 36 Harv. Int'l. L.J. 373, 416.

52 Under the English common law rules of jurisdiction, personal jurisdiction depends on lawful service of the claim form on the defendant.

${ }^{53}$ See, on the in personam operation of injunctive relief in general, Paterson J.M., Kerr on Injunctions (London: Sweet and Maxwell, $6^{\text {th }}$ edition, 1927).
} 
private international law rules. Support for this approach is found in the following important passage from Mann's Hague Lecture:

"The mere fact that a state's judicial or administrative agencies are internationally entitled to subject a person to their personal or 'curial' jurisdiction does not by any means permit them to regulate by their orders such person's conduct abroad. This they may do only if the state of the forum also has substantive jurisdiction to regulate conduct in the manner defined in the order. In other words, for the purpose of justifying, even in the territory of the forum, the international validity of an order, not only its making, but also its content must be authorised by substantive rules of legislative jurisdiction." 54

The fundamental mistake of the English courts in relation to the international scope of freezing injunctions is their failure to implement the above distinction advocated by Mann. The Court of Appeal has expressly confirmed that "in relation to the grant of worldwide relief, the jurisdiction is based on assumed personal jurisdiction". ${ }^{55}$ Although as has been descrived above in section IV there is some evidence of a more cautious approach, this distinction should be made more clearly in future cases. ${ }^{56}$

The concept of subject-matter jurisdiction is concerned with jurisdiction over the subject matter of the proceedings. A well-known example of a case concerned with the application of this concept is the so-called Moçambique rule. ${ }^{57}$ However, unnecessary confusion has arisen because the concept of subject-matter jurisdiction has been incorrectly used in a number of English cases. ${ }^{58}$ In a number of cases, the courts effectively refused to exercise their discretion to grant an order against defendants who were subject to the court's personal jurisdiction due to concerns about interference with the sovereignty of the foreign courts. However, the explanation for this conclusion was the lack of subject-matter jurisdiction. The incorrect use of the concept of the subject-matter jurisdiction stems from Mackinnon $v$ Donaldson, Lufkin \& Jenrette ${ }^{59}$ where the claimant sought an order under the Bankers' Books Evidence Act 1879 against the London branch of a New York bank and a subpoena addressed to one of its officers to produce documents with respect to accounts governed by New York law. The claimant was unsuccessful even though the court had personal jurisdiction over the bank. Hoffmann J (as he then was) rejected the claimant's argument that the defendant bank, having submitted to the English court's jurisdiction, could be required to comply with a subpoena in the same way as an English company. His reasoning was that the claimant's argument

\footnotetext{
54 Mann F.A., 'The Doctrine of Jurisdiction in International Law' (1964) 111 Recueil des Cours 1, 146. See also: Mann F.A., 'The Doctrine of Jurisdiction Revisited after Twenty Years' (1984-III) 186 Recueil des Cours 19 (reproduced in Mann F.A., Further Studies in International Law (Oxford: Clarendon Press, 1990); McLachlan C., 'Transnational Applications of Mareva Injunctions and Anton Piller Orders' (1987) ICLQ 669, 676.

${ }^{56}$ See the section of this article entitled "Evidence of a more cautious approach".

${ }^{56}$ See the section of this article entitled "Evidence of a more cautious approach".

${ }^{57}$ British South Africa Co v Cia de Moçambique [1893] AC 602.

58 See Mackinnon v Donaldson, Lufkin \& Jenrette [1986] Ch. 482, Societe Eram Shipping Co Ltd v Cie Internationale de Navigation et al [2004] 1 AC 260, and Parbulk II AS v PT Humpuss (The Mahakam) [2011] EWHC 3143 (Comm). For similar criticism of the use of the concept of subject-matter jurisdiction, see Hartley T., 'Jurisdiction in Conflict of Laws - Disclosure, Third-party Debt and Freezing Orders' (2010) LQR 194, 197.

59 [1986] Ch. 482.
} 
"confuses personal jurisdiction, i.e., who can be brought before the court, with subject-matter jurisdiction, i.e., to what extent the court can claim to regulate the conduct of those persons. It does not follow from the fact that a person is within the jurisdiction and liable to be served with process that there is no territorial limit to the matters upon which the court may properly apply its own rules or the things which it can order such a person to do." 60

Hofmann J's conclusion could have been justified without any reference to subjectmatter jurisdiction. ${ }^{61}$ The outcome in this case was correct but the reasoning should have been different.

The court's decision was based on its refusal to exercise discretion to grant the order due to the possible interference with the sovereignty of the foreign courts. ${ }^{62}$ The decision in Mackinnon is useful in reminding us about the importance of the argument that personal jurisdiction over the defendant should not be a sufficient requirement to establish the English court's jurisdiction to grant a freezing injunction. The first reason is the need to respect the interests of other states and their own right to regulate the conduct of defendants. The second and related reason is that interference with the sovereignty of other states could lead to the application of conflicting procedural rules in relation to the same assets. This would be unfair to the defendants and any third-party holders of the assets and inconsistent with their legitimate expectations about the applicable regulatory framework. To achieve a level playing field in international litigation, claimants must be prevented from making multiple applications for interim relief with respect to the same assets. It will be argued that the problems of illegitimate encroachment and unfairness to defendants would be resolved by imposing a new requirement that the English court has jurisdiction over the property (the assets) for which the injunction is being sought. ${ }^{63}$ Such a requirement would be consistent with a key characteristic of freezing injunctions, their quasi-proprietary nature, to which we will turn in the next section.

In the context of freezing injunctions, the current position appears to be that subject-matter jurisdiction is incorrectly equated with the question of whether there is a sufficient connection between the defendant and the English court. ${ }^{64}$ In The Mahakam, the court had personal jurisdiction over HSTPL; however, it was held that a freezing injunction should only be granted with regard to its assets in England. ${ }^{65}$ The justification for the refusal to grant a worldwide injunction was that the defendant's connection to the English court

\footnotetext{
${ }^{60}$ Ibid, 493.

${ }^{61}$ For evidence of confusion arising from the application of Hoffmann J's reasoning in the context of freezing injunctions, see Spry I.C.F., Equitable Remedies (Thomson Reuters Australia, $9^{\text {th }}$ edn, 2013) who seems to suggest that, in the light of Mackinnon, "subject-matter jurisdiction" may be required where a freezing injunction is sought in respect of assets located abroad. For judicial application of the concept in the context of freezing injunctions, see Parbulk II AS v PT Humpuss (The Mahakam) [2011] EWHC 3143 (Comm).

${ }^{62}$ For Hoffmann J's concerns about sovereignty, see especially [1986] Ch. 482, 494.

${ }^{63}$ For the details of this proposal, see the section of this article entitled "The first option: jurisdiction over the assets".

${ }^{64}$ See Parbulk II AS v PT Humpuss (The Mahakam) [2011] EWHC 3143 (Comm). Similarly, in Masri v Consolidated Contractors International (UK) Ltd [2009] Q.B. 450, the concept of subject-matter jurisdiction was also equated with sufficient connection.

${ }^{65}$ [2011] EWHC 3143 (Comm), [98].
} 
was "minimal" as it arose only as a result of the failure of HSTPL to challenge its jurisdiction. ${ }^{66}$ Had HSTPL challenged the jurisdiction of the English court, Gloster J (as she then was) would have discharged the order granting the claimant permission to serve the arbitration claim form on HSTPL out of the jurisdiction. In such circumstances, and drawing upon the words of Lawrence Collins LJ in Masri (No 2), Gloster J concluded that there was no "subject-matter jurisdiction" to grant relief with respect to assets located abroad because of the absence of a sufficient connection with England. ${ }^{67}$

The concept of subject matter jurisdiction has been imported into English law from North America where it is primarily used to explain that some cases cannot be heard by certain courts (e.g. federal courts). It can be seen from Mackinnon and The Mahakam that the English interpretation of the concept of subject matter jurisdiction has distorted its traditional meaning. Putting aside the confusion about the meaning of subject-matter jurisdiction, there is insufficiently clear guidance from the English case law about the circumstances in which the court would find that there is a sufficient connection. ${ }^{68}$ This in turn means that based on the current interpretation of the concept in The Mahakam, it is not possible to provide a straightforward answer to the question of whether the requirement of subject-matter jurisdiction is satisfied in a given case. Resolution of this uncertainty is urgently needed. The English courts must clarify that the concept of subjectmatter jurisdiction has nothing to do with the discretionary question of whether it is appropriate to exercise jurisdiction in a particular case based on the degree of connection with the forum. ${ }^{69}$ To clarify this point, the courts should make reference to the correct use of the concept of subject-matter jurisdiction by the Supreme Court in Lucasfilm $v$ Ainsworth. ${ }^{70}$ The concept of subject matter jurisdiction is actually concerned with whether the facts and matters forming the basis of the claim or defence may be the object of adjudication by the court. Thus, it can be said, by way of an example, that the so called Moçambique rule was based on the lack of subject matter jurisdiction. ${ }^{71}$ It follows that the concept of subject-matter jurisdiction should be regarded as irrelevant in the context of applications before the English courts for a freezing injunction.

\section{The quasi-proprietary nature of freezing injunctions}

It is submitted that it is inconsistent with the international systemic perspective on the purpose of private international law rules for English courts to extend the international scope of collateral freezing injunctions to assets located abroad. The courts should recognise that freezing injunctions indirectly regulate the rights and obligations arising from the property or contract covered by the order. The dispute between the parties over whether a defendant's conduct justifies a freezing order is effectively a dispute about whether a defendant should be temporarily deprived of the benefits under the law that

\footnotetext{
${ }^{66}$ Ibid, [95].

${ }^{67}$ Ibid.

${ }^{68}$ This is especially true in cases involving the defendant's conduct relating to his assets located abroad. See, for example, Royal Bank of Scotland PIC v FAL Oil Company Ltd [2012] EWHC 3628 (Comm) and, more recently, Eastern European Engineering Ltd v Vijay Construction (Proprietary) Ltd [2018] EWHC 1539 (Comm).

${ }^{69}$ This interpretation of the concept of subject-matter jurisdiction is consistent with that adopted by Briggs $A$., Private International Law in English Courts (OUP: Oxford, 2014), pp. 169-171.

70 [2012] 1 A.C. 208.

${ }^{71}$ British South Africa Co v Cia de Moçambique [1893] AC 602.
} 
governs the property or contract in question. A defendant against whom the injunction has been granted is deprived of the two essential features of property rights: the ability to freely transfer the asset and to exclude third parties from interfering with the asset. ${ }^{72}$ For these reasons, a freezing injunction could be classified as a quasi-proprietary form of relief that involves an indirect interference with contractual or property rights. It is true that armed with a freezing injunction, a claimant does not have a proprietary right to the defendant's assets. ${ }^{73}$ However, as Tomlinson $\sqcup$ explained, "in many cases...a freezing order has the practical if not theoretical effect of giving security to the claimant for its claim" ${ }^{74}$

To provide further justification for this proposed classification, emphasis is placed on the ability of claimants to combine a freezing injunction with other orders to facilitate future enforcement against the assets covered by the freezing injunction. Such other orders include receivership orders and orders to transfer assets from one jurisdiction to another ('turnover orders').

With regard to turnover orders, in Derby $v$ Weldon (No. 6) ${ }^{75}$, it was held that the English courts even have a power to order the defendant to transfer his assets from one jurisdiction to another. The Court of Appeal's reasoning was that the in personam jurisdiction of the English court is "unlimited". Dillon $\amalg$ stated that the jurisdiction extended to

\begin{abstract}
"ordering the transfer of assets to a jurisdiction in which the order of the English court after the trial of the action will be recognised, from a jurisdiction in which that order will not be recognised and the issues would have to be relitigated, if...the only connection of the latter jurisdiction with the matters in issue in the proceedings is that moneys have been placed in that jurisdiction in order to make them proof against the enforcement, without a full retrial in a foreign court, of any judgment which may be granted to the plaintiffs by the English court in this action or indeed if the only connection with the latter jurisdiction is financial, as a matter of controlling investments." 76
\end{abstract}

If a defendant company is merely subject to the English court's personal jurisdiction, this ought to be treated as an insufficient connection to enable the court to order a defendant to take positive steps in another jurisdiction in relation to a bank account not governed by English law. This decision provides a clear example of an order that directly interferes with the defendant's rights under a contract governed by foreign law.

Writing extra-judicially, Lord Browne-Wilkinson explained that "the fiction that [a freezing injunction] only operates in personam becomes very thin indeed when the English court appoints a Receiver. Such an order does not operate only in personam: under English law, the Receiver is entitled to take possession of the assets." 77 Indeed, the court can appoint a receiver for assets located abroad either pre-judgment or post-judgment in

\footnotetext{
${ }^{72}$ See Gray K., 'Property in Thin Air' (1991) 50 C.L.J. 252.

${ }^{73}$ Cretanor Maritime Co Ltd v Irish Marine Management Ltd (The Cretan Harmony) [1978] 1 W.L.R. 966.

${ }_{74}^{74}$ Energy Venture Partners Ltd v Malabu Oil and Gas Ltd [2014] EWCA Civ 1295, [52].

75 [1990] 1 W.L.R. 1139.

${ }^{76}$ Ibid, 1151C-E.

${ }^{77}$ Browne-Wilkinson N., 'Territorial Jurisdiction and the New Technologies' (1991) 25 Isr. L. Rev. 145.
} 
support of a freezing injunction if there is a real risk that the defendant will disobey the freezing injunction. ${ }^{78}$ To be more specific about the circumstances in which a receivership order will be made, as explained by the Court of Appeal in JSC BTA Bank v Ablyazov, ${ }^{79}$

"If...the method by which a defendant beneficially holds his assets is transparent, a receivership order may well not be necessary. But if it is opaque and there is a reasonable suspicion that such opacity will be used by a defendant to act in breach of a freezing order, it may well be the case that a receivership order is appropriate" ${ }^{80}$

Agreeing with and reinforcing the above views of Lord Browne-Wilkinson, one American author notes that

"[g]iven the broad sweep of the prohibitions outlined in the [freezing] order and the debilitating effect the mere imposition of the order has on conducting business, it is doubtful that the distinction [between in personam and in rem] is of any meaningful, practical significance to a defendant...It makes little difference to a defendant whether his business has been "frozen" or "seized" by a foreign court. Either way, it is a slender reed on which to hang such a violation of international principles of sovereignty." 81

The distinction between in personam and in rem becomes even less significant when we consider the claimant-friendly attitude of the English courts towards the enforcement of worldwide freezing orders in certain jurisdictions. For a claimant to enforce a worldwide freezing order in another jurisdiction, it is necessary to obtain permission from the English court and subsequently from the foreign court. When considering whether to give such permission and how to exercise its discretion, the English court will apply the guidelines developed in Dadourian Group International Inc. $v$ Simms, ${ }^{82}$ known simply as the 'Dadourian guidelines'. The guidelines, inter alia, specifically ask the court to take into account the nature of the relief sought from the foreign court and in particular whether that relief would be "superior" to the existing relief obtained from the English court. Taken at its face value, it appears from this guideline that the in personam nature of English freezing orders should not be converted into a superior form of local relief with proprietary consequences. However, the practical reality is that an English court may well take a pro-claimant stance on this issue. This is evident from the recent decision of Males J in Arcadia Energy (Suisse) SA et

\footnotetext{
${ }^{78}$ Cruz City 1 Mauritius Holdings v Unitech Limited [2014] EWHC 3131 (Comm), [50] per Males J. This was a case where a receiver was appointed post-judgment in respect of the defendants' assets located abroad in support of a worldwide freezing order.

79 [2010] EWCA Civ 1141 (a case where a receivership order was made in support of a freezing injunction because, inter alia, the assets were difficult to trace and there was inadequate disclosure).

${ }^{80}$ Ibid, [14].

${ }^{81}$ Wilson J.L., 'Three If By Equity: Mareva Orders \& the New British Invasion' (2004-2005) 19 St John's J. Legal Comment 673, 709 and 735 (footnotes omitted). In support of his thesis, Wilson refers, inter alia, to Crawford's description that the effect of a freezing injunction is similar to a "conditional attachment": Crawford J., 'Execution of Judgments and Foreign Sovereign Immunity (1981) 75(4) Am. J. Int'I L. 820.

82 [2006] EWCA 399.
} 
al. v Attock Oil International Ltd. et al. ${ }^{83}$ The defendants (including former company officers) argued that the claimants (petroleum companies) should be refused permission to enforce the worldwide freezing order in Switzerland and Lebanon. One of the defendants' submissions was that the remedies sought from the Swiss and Lebanese courts were in rem and therefore superior to the English order. Males $\mathrm{J}$ acknowledged that the relief sought from the Swiss courts operated in rem but nevertheless rejected the defendant's argument, observing that it was common practice to grant permission for enforcement in such circumstances. His Lordship noted that the superior form of foreign relief was not an absolute bar to permission. As an example of circumstances in which permission might be refused on grounds of superiority, it was observed that the foreign order should not prevent the use of funds in accordance with the provisos in the English order (such as the ability to use the funds for the purposes of legal costs and living expenses). Although the liberal approach of the court in Arcadia Energy may have been influenced by the seriousness of the allegations of widespread fraud against the defendants, it cannot be denied that the common practice in the Commercial Court of granting permission in circumstances where the foreign order operates in rem dilutes the importance of the distinction between in personam and in rem. ${ }^{84}$

\section{E. Reflections on the theoretical flaws in the current framework}

Given the lack of importance attached to the question of the existence of jurisdiction and the fact that the only device for controlling the scope of relief is the test of expediency at the discretionary stage, the current position demonstrates a unilateral approach to the existence of jurisdiction to grant a worldwide freezing injunction in support of foreign proceedings. A unilateral approach tends to give disproportionate weight to the forum's policies and ignores the internationalist and systemic goals of private international law and its public international law roots.

There are numerous examples in English cases of using a unilateral approach to determine the existence of jurisdiction to grant a collateral freezing injunction. One way of

\footnotetext{
${ }^{83}$ [2015] EWHC 3700 (Comm). For a different-but-related issue of whether it is possible for the claimant to seek orders from the foreign court of a different nature (such as arrest of a vessel) in addition to the English order, see Re LMAA Arbitration [2013] EWHC 895 (Comm) where the court arguably took a claimant-friendly stance in that the claimant was not in breach of an undertaking not to seek "an order of a similar nature" under the worldwide freezing order by arresting a vessel and thereby obtaining security abroad. An analogy could be made with the liberal approach of the US Court of Appeals for the Fifth Circuit in The Belcher Company of Alabama Inc. v. M/V Maratha Mariner 724 F.2d 1161 (5th Cir. 1984) (action in rem for the arrest was allowed despite parallel 'in personam' proceedings in the Netherlands).

${ }^{84}$ The significance of the distinction is further diluted in light of the decision of the New York court to recognise and enforce English default judgments resulting from non-compliance with an English freezing injunction in CIBC Mellon Trust Co. v Mora Hotel Corp., 100 N.Y. 2d 215, 222 (2003). See, also, the decision of the Swiss Federal Supreme Court in ATF 4A.366/2011 (31 October 2011), which "confirms the assumption that a party in the possession of a WFO [worldwide freezing injunction] has a legitimate interest in obtaining a declaration of enforceability from a Swiss court": Scherer M. and Nadelhofer S., 'Possible Enforcement of Worldwide Freezing Orders in Switzerland' http://kluwerarbitrationblog.com/blog/2012/03/23/possibleenforcement-of-worldwide-freezing-orders-in-switzerland/; Giroud, S., 'Do you speak Mareva? How Worldwide Freezing Orders are Enforced in Switzerland' (2012/2013) 14 Yearbook of Private International Law 443.
} 
illustrating this is by comparing the reasoning of Rix J with that of the majority of the Court of Appeal in Refco $v$ Eastern Trading. Instead of addressing the question of the existence of jurisdiction to grant relief, the Court of Appeal in Refco first considered whether the substantive preconditions for the English freezing injunction had been satisfied and then immediately proceeded to apply the test of expediency. This series of actions means that the Court of Appeal made an assumption that jurisdiction exists to grant the order and that the only question relating to jurisdiction was whether to exercise its discretion to grant relief. The approach taken by the Court of Appeal should be contrasted with that of Rix J (as he then was) in the Commercial Court. His concern was to determine from the outset whether the English court or the American court was responsible for considering the merits of the application for interim relief as evident from the second paragraph of his judgment:

"I have...formed the firm view that the primary responsibility in this case for considering whether there should be interim relief by way of some form of attachment of assets, by some means analogous to what we in this jurisdiction call the Mareva injunction, should fall to the United States Court which is seised with the merits of the dispute between the parties before me, rather than to this Court." ${ }^{85}$

In Rix J's view, it was for the American court to consider the impact of the exclusive jurisdiction clause, which was potentially sufficient on its own to preclude the defendants from applying for interim relief in England. As Rix J's conclusion was that the relevant American procedural rules on interim relief (including their equivalent of the test for dissipation of assets) were applicable, he was cautious not to express any views on the application of substantive preconditions for the English freezing injunction. ${ }^{86}$ The approach taken by Rix $\mathrm{J}$ is consistent with the need to consider whether the English rules on interim relief are applicable at all, even if the English court has in personam jurisdiction over a defendant. His multilateral analysis of the connections to England and Illinois focused on the application for interim relief with the aim of identifying the most appropriate forum to determine the merits of that application. Rix J did not make the assumption that section 25 of the 1982 Act gave him unlimited regulatory authority to apply the English rules on interim relief subject only to the vague requirement that its exercise would be inexpedient. Overall, Rix J's approach ensured that the English procedural rules did not encroach upon what he saw as the American court's exclusive jurisdiction to consider whether the defendant's conduct warranted American forms of interim relief.

\section{Proposals for reform}

\section{A. The bold solution: an international instrument}

Consistent with the theoretical position adopted in this article, the ideal means for allocating jurisdiction to grant a freezing injunction would be an international instrument. Regarding the basis of allocating jurisdiction, only one country's courts should have adjudicatory jurisdiction and regulatory authority to determine an application for a freezing

\footnotetext{
85 [1999] 1 Lloyd's Rep. 159. 160.

${ }^{86}$ [1999] 1 Lloyd's Rep. 159, 161.
} 
injunction with respect to one set of assets. In other words, adjudicatory jurisdiction and regulatory authority in the field of freezing injunctions should be exclusive. By allocating jurisdiction on an exclusive basis, the scope of each country's procedural rules concerning freezing injunctions (or similar relief) would be equal. There would be no possibility for overlapping assertions of jurisdiction to grant injunctive relief and therefore no possibility of conflict of procedural laws. Exclusive jurisdiction would eliminate the possibility of encroachment upon another country's sovereignty.

Further support for this proposal is found in the reasoning of the United States Supreme Court in Grupo Mexicano de Desarrollo S.A. v Alliance Bond Fund Inc $^{87}$ and the Court of Appeals of New York in Credit Agricole v Rossiyskiy Kredit Bank ${ }^{88}$ Both courts were adamant in rejecting the argument that the current English approach (the availability of worldwide freezing injunctions) should be adopted in the United States. The courts made convincing observations about "the profound effects that the availability of world-wide Mareva injunctions would have on world-wide commerce" and explained that "the widespread use of [worldwide freezing injunctions] would drastically unbalance existing creditors' and debtors' rights....and substantially interfere with the sovereignty and debtor/creditor/bankruptcy laws of, and the rights of interested domiciliaries in, foreign countries." ${ }^{89}$ The position taken in the United States provides a powerful argument in favour of restricting the current international scope of English freezing injunctions. Exclusive jurisdiction would be beneficial for the English courts in that it would eliminate the risk of foreign courts interfering with the sovereignty of the English courts. ${ }^{90}$ There is evidence in a number of cases involving orders of foreign courts (outside the field of freezing injunctions) where the English courts have expressed concerns about the purported interference with sovereignty. ${ }^{91}$ For the above reasons, the bold solution would promote the functions of private international law rules under the international systemic perspective. It would be consistent with the need to take into account principles of public international law when constructing private international law rules in a specific area of the law. Under the bold solution, the limited international scope of these injunctions would also reflect the fact that a freezing injunction is an exception to the general rule on non-interference with the defendant's property rights before judgment. ${ }^{92}$ The next question is which country's courts should have exclusive jurisdiction when there are connections to more than one country?

\footnotetext{
${ }^{87} 527$ US 308 (1999). For a critique of the majority's reasoning see Capper D. 'The Need for Mareva Injunctions Reconsidered' (2005) 73 Fordham L. Rev. 2161; Collins L., 'United States Supreme Court Rejects Mareva Jurisdiction' (1999) 115 LQR 601.

88729 N.E.2d 683 (N.Y. 2000).

89729 N.E.2d 683 (N.Y. 2000), 689 per Levine J.

${ }^{90}$ See, in general, Slaughter A.-M., 'Sovereignty and Power in a Networked World Order' (2004) 40 Stan. J. Int'l. L. 283 (arguing that "[s]tates can only govern effectively by actively cooperating with other states and by collectively reserving the power to intervene in other states' affairs"). See also Parrish A.L., 'Reclaiming International Law from Extraterritoriality' (2008-9) 93 Minn. L. Rev. 815 (arguing that international problems should be solved by resort to international law and international instruments rather than by means of extraterritorial application of national law); Simon A.M. and Waller S.W., 'A Theory of Economic Sovereignty: An Alternative to Extraterritorial Jurisdictional Disputes' (1986) 22 Stan J Int'I L. 337.

${ }^{91}$ See, inter alia, British Nylon Spinners Ltd v Imperial Chemical Industries Ltd [1952] 2 All ER 780; Rio Tinto Zinc Corporation v Westinghouse Electric Corporation [1978] 1 All ER 434; X AG v A bank [1983] 2 All ER 464; Libyan Arab Foreign Bank v Bankers Trust [1989] 1 Q.B. 728.

92 Lister \& Co v Stubbs (1890) 45 Ch.D. 1.
} 
Principles of public international law do not provide an instant answer as to the appropriate connecting factor. Under public international law, the preferable view is that there is no hierarchy of principles of jurisdiction. ${ }^{93}$ Both territorial and personal connecting factors should be treated as equally valid justifications for the assertion of adjudicatory jurisdiction. Nevertheless, it is still possible to identify, on an a priori basis, a single connecting factor for all applications for freezing injunctions that would ensure a fair and just allocation of regulatory authority to apply procedural rules on asset preservation. It is at this identification stage that we turn to the "private" element of private international law by considering the characteristics of freezing injunctions and the interests of all stakeholders, including the holder of the assets.

The English courts have placed significance on the connection between the defendant and the forum because they see a freezing injunction as operating only against the person and not against the assets. However, it has been argued that English courts should recognise the quasi-proprietary nature of freezing injunctions. Moreover, the narrow perception of the function of a freezing injunction as a weapon against unscrupulous defendants ignores the principle of equipage equality. ${ }^{94}$ If we accept the quasi-proprietary nature of freezing injunctions and the important role of equipage equality, what should be the single connecting factor for adjudicatory jurisdiction (and in turn the application of the forum's rules on asset preservation)? Exclusive jurisdiction should be given to the courts of the country where the assets are located. This rule of jurisdiction should apply to all cases involving applications for freezing injunctions in support of foreign proceedings. This approach is consistent with the principles of territoriality and subsidiarity. The diversity of each country's rules on asset preservation relief and their underlying values and policies would be protected, promoting justice pluralism. ${ }^{95}$ For this reason, such a framework would enhance international judicial co-operation. ${ }^{96}$ It would ensure a horizontal, multilateral, and international approach to the existence of jurisdiction in this field. The proposed private international law framework for freezing injunctions would be consistent with the territorial scope of the related framework for property freezing orders in the criminal law context as evident from Serious Organised Crime Agency v Perry. ${ }^{97}$

If we now assume that the bold proposal is adopted and the English court does have exclusive jurisdiction to grant a freezing injunction with respect to assets located in England, should the court have any discretion to refuse to exercise its jurisdiction? If so, what is the proper role of discretion in such circumstances? To create an equitable balance of rights between the parties, it would be necessary for the court to have some (albeit very limited)

\footnotetext{
${ }^{93}$ See Bianchi A., 'Unity v. Fragmentation: The Customary Law of Jurisdiction in Contemporary International Law' in Meessen K.M. (ed.) Extraterritorial Jurisdiction in Theory and Practice (Kluwer Law International, 1996), p. 74 where he explains that there is a disagreement over this issue (for example, Oppenheim takes the view that priority should be given to the principle of territoriality).

${ }^{94}$ Saranovic F., 'Rethinking the Scope of Freezing Injunctions' (2018) 37 CJQ 383.

${ }^{95}$ Thus, the proposed framework is different from the European Account Preservation Order (EAPO), which essentially involves the harmonisation of the substantive preconditions for granting freezing injunctions: see Regulation (EU) No 655/2014 of the European Parliament and of the Council of 15 May 2014 establishing a European Account Preservation Order procedure to facilitate cross-border debt recovery in civil and commercial matters.

${ }^{96}$ On international judicial co-operation, see Schlosser P., 'Jurisdiction and International Judicial and Administrative Co-Operation' (2000) 284 Recueil des Cours.

${ }^{97}$ [2012] UKSC 35.
} 
discretion to refuse to grant an injunction. Two main factors should be considered at the discretionary stage. First, it would be relevant to take into account any applications by the claimant for asset preservation relief in any foreign courts. In instances where the claimant has already obtained some relief abroad, it would be necessary to consider whether a freezing injunction from the English court would create undue pressure for the defendant. Second, it would be relevant to take into account any delay on the claimant's part in applying for a freezing injunction. Although there is some existing case law on the issue of delay in interim injunctions, ${ }^{98}$ this is a fact-sensitive issue and there is limited value in any attempt to derive concrete guidance from the case law.

Given the practical difficulties of reaching agreement on an international instrument, it is useful to seek a more modest solution to the excessive international scope of freezing injunctions. What could be done at the domestic level to bring English law in this field closer to the international systemic approach and ensure a more equitable balance of rights between the parties?

\section{B. Options for a modest solution}

1. The first option: jurisdiction over the assets

In summary, under the first modest proposal, the requirements for obtaining injunctive relief would be as follows:

(1) Personal jurisdiction over the defendant. ${ }^{99}$

(2) Jurisdiction over the assets (jurisdiction in rem) regarding the order that is sought. This requirement would only be satisfied if the assets are located in England.

(3) If the above requirements relating to the existence of jurisdiction are satisfied, then the English court should still be able to refuse to exercise its jurisdiction to grant the injunction. This discretion should be limited in scope. At this discretionary stage, the court should take into account any applications for asset preservation relief in foreign courts. Any unexplained delay on the claimant's part should also be relevant. Under the proposal for this new discretionary stage, the courts would dispense with the unnecessary and uncertain principles of expediency and comity.

(4) It would be essential for the claimant to fulfil all the substantive preconditions and provide the necessary safeguards and provisos.

\section{The second option}

\footnotetext{
${ }^{98}$ See, for some examples in the context of other interim injunctions, Raks Holdings AS v Ttpcom Ltd [2004] EWHC 2137 (Ch); AAH Pharmaceuticals Ltd et al v Pfizer Ltd \& another [2007] EWHC 565 (Ch).

${ }^{99}$ Lawful service of the claim form in England or lawful service of the claim form out of the jurisdiction would satisfy this requirement.
} 
One alternative option is for the courts to highlight an express requirement for judges to consider whether the English court is the most appropriate forum to respond to the claimant's application for asset preservation relief. This proposal seeks to address the problem of encroachment through a more rigorous discretionary stage by forcing the courts to distinguish between orders with respect to assets located in England and orders with respect to assets located abroad. This option is based on the assumption that English courts may be more receptive to the idea of restricting the international scope of collateral freezing injunctions in a less rigid manner.

It is possible for the courts to give prominence to the enquiry about the most appropriate forum by drawing upon statements in the existing case law on freezing injunctions. For example, Males J should be applauded for separately addressing the question of jurisdiction to grant the injunction from the issue of discretion to grant the relief. This was in Cruz City 1 Mauritius Holdings v Unitech, in which he stated the following:

"If I am wrong as to jurisdiction, the question of discretion arises...Accordingly the claimant must show that England is clearly the most appropriate forum for the determination of the application for a freezing order against the Chabra defendants". ${ }^{100}$

This is a rare case involving a freezing injunction where the court explicitly asked the question of whether England is "clearly the most appropriate forum" for the determination of the application for a freezing order. In addition to Male J's judgment in Cruz City 1, the courts could also highlight and place reliance on the judgment of Rix $\mathrm{J}$ in Refco $v$ Eastern Trading. Thus, the key ingredients for this modest solution already exist in some judgments.

\section{Conclusions}

The current application of private international law rules in collateral freezing injunction cases is excessively claimant-friendly, and it is inconsistent with the underlying purpose of the freezing injunction - to create a level playing field in litigation. The courts seem to be 'bending over backwards' to justify their conclusion that it is expedient to grant a collateral freezing injunction, especially in cases involving allegations of international fraud. By tailoring the rules of jurisdiction in a claimant-friendly manner, the courts are ignoring, to some extent, the interests of foreign states. The most potent illustration of this is the possibility for a claimant to obtain a collateral worldwide freezing injunction from the English court even where there is no connection at all with England. One of the most fundamental theoretical flaws inherent in the current framework is that private international law is seen simply as a component of national private law concerned with achieving substantive justice.

The preferable theoretical stance is that we have to take into account the international function of private international law: the allocation of regulatory authority between different legal systems. Regulatory authority should be allocated in accordance with certain values. Although there is potential for disagreement about what these values

${ }^{100}$ [2014] EWHC 3131 (Comm). 
should be, the author would agree with Mills that justice pluralism and subsidiarity are among the most important values. Preserving the diversity of national rules on interim relief and avoiding any conflict of procedural laws (overlapping exercises of regulatory authority) would be consistent with these values. The rules of private international law must ensure the freedom and equality of all sovereign states to apply their own policies on interim relief. Although the proposed international instrument would fulfil the basic requirements, even the adoption of one of the two modest proposals would have the beneficial effect of encouraging other states to take the same steps or resist any future temptation to expand the international scope of similar relief. In contrast with some perceptions, encouraging other states to avoid extraterritorial injunctive relief is in the long-term interest of the English courts and London's status as a leading international centre for financial and legal services. 